\title{
RURAL DEVELOPMENT PROGRAM AND ITS IMPACT ON RURAL DEVELOPMENT (ON THE EXAMPLE OF THE WEST POMERANIAN VOIVODESHIP)
}

\author{
MAŁGORZATA GORZAŁCZYŃSKA-KOCZKODAJ, ${ }^{1}$ RAFAŁ KOCZKODAJ ${ }^{2}$
}

${ }^{1}$ University of Szczecin, Faculty of Management and Economics of Services, POLAND

e-mail:m.g.koczkodaj@wzieu.pl

${ }^{2}$ WSB University of Poznań, Faculty of Economics of Szczecin, POLAND

e-mail: rafal.koczkodaj@wsb.szczecin.pl

RECEIVED
ACCEPTED
JEL
CLASSIFICATION

KEYWORDS

ABSTRACT
10 December 2018

28 December 2018

Q12, Q14, Q19

Common Agricultural Policy, rural areas, rural development, West Pomeranian Voivodeship

The aim of the article is to analyze and assess the diversity of the volume of funds used under the Rural Development Program (RDP) divided into two periods, 2007-2013 and 2014-2020 in the West Pomeranian Voivodeship. A research question was posed as to how these measures influenced rural development and the activation of rural residents. The research was carried out on the basis of statistical data analysis methods as well as comparative analyzes. The data from the Local Data Bank of the Central Statistical Office, the voivodeship labour office, the West Pomeranian Voivodeship and the Agency for Restructuring and Modernization of Agriculture were used for the research. On the basis of the analysis of the use of EU funds under the RDP, it can be pointed out that they were transferred to the objectives serving rural development and certainly contributed to the development of the Polish countryside, reducing its level of backwardness, poverty and unemployment rate.

\section{Introduction}

The process of integration with the European Union has contributed to significant changes in the policy of rural development in Poland (Zięba, Kowalski, 2007, pp. 187-191). Common Agricultural Policy, structural funds and other EU instruments have strengthened the increasingly multifaceted view of rural development. Poland is one of the 
largest beneficiaries of Common Agricultural Policy funds and cohesion policy in the EU. Sectoral orientation is complemented by a territorial perspective through the European Agricultural Fund for Rural Development (EAFRD).

Rural areas are important for Poland - they are inhabited by about $35 \%$ of the country's population and they produce about one-quarter of gross domestic product. In the context of stable economic growth, the Polish countryside has developed impressively (GDP growth per capita in rural areas by 61\% in 2000-2014) (OECD, 2018). In comparison to other rural areas of the OECD, in the Polish countryside, the increase in GDP per capita is one of the highest, partly due to the catching-up process. Despite such extraordinary results of economic growth, the majority of rural regions did not match the national GDP per capita.

\section{Characteristics of the West Pomeranian Voivodeship}

The West Pomeranian Voivodeship is the fifth largest region of Poland, with an area of 22.9 thousand km2, and the eleventh in terms of the number of residents, most of whom live in cities.

Despite the high degree of urbanization, agriculture is one of the key branches for the region's economy. The condition of West Pomeranian agriculture was significantly strengthened as a result of Poland's accession to the European Union. In the years preceding the accession (2001-2003), the average value of global agricultural production, realized by farmsteads operating in the West Pomeranian Voivodeship, amounted to PLN 2,291 million and in 2009-2016 - PLN 3,526 million (Malkowski, 2017, p. 2).

Funds transferred under the Rural Development Program, both in the years 2007-2013 and 2014-2020, had an impact not only on the increase in agricultural production thanks to measures serving the development of rural areas but also indirectly affected the unemployment rate of rural residents.

The unemployment rate in the West Pomeranian Voivodeship for a long period was higher than the average rate of unemployment in the country. The situation has improved since 2013. At the end of December 2017, the total of more than 1 million unemployed people remained in the registers of labour offices in the country, while registered unemployment in the West Pomeranian Voivodeship was 8.7\% (Wojewódzki Urząd Pracy w Szczecinie, 2018).

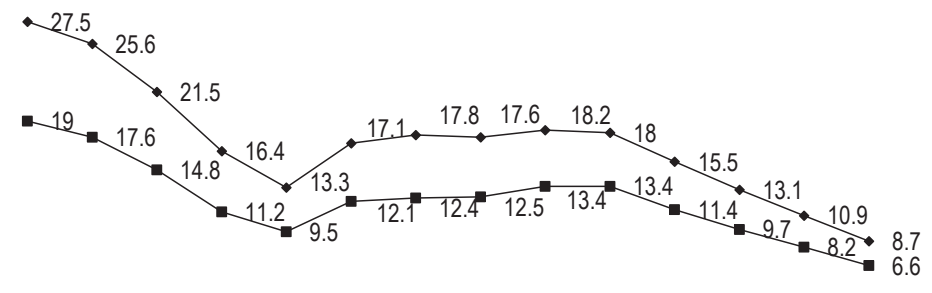

\begin{tabular}{|c|c|c|c|c|c|c|c|c|c|c|c|c|c|}
\hline ষ্ঠ & 용 & \&্ণ & 용 & 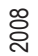 & 요 & 응 & ్ㅗ & $\stackrel{\sim}{\check{\delta}}$ & $\frac{m}{\delta}$ & 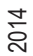 & 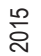 & $\frac{\infty}{\delta}$ & 등 \\
\hline
\end{tabular}

Figure 1. The registered unemployment rate in 2004-2017 (\%)

Source: own study based on data from the voivodeship labour office. 
The situation of declining unemployment both in relation to Poland and the West Pomeranian Voivodeship, has a strict impact on unemployment in rural areas (Figure 2).

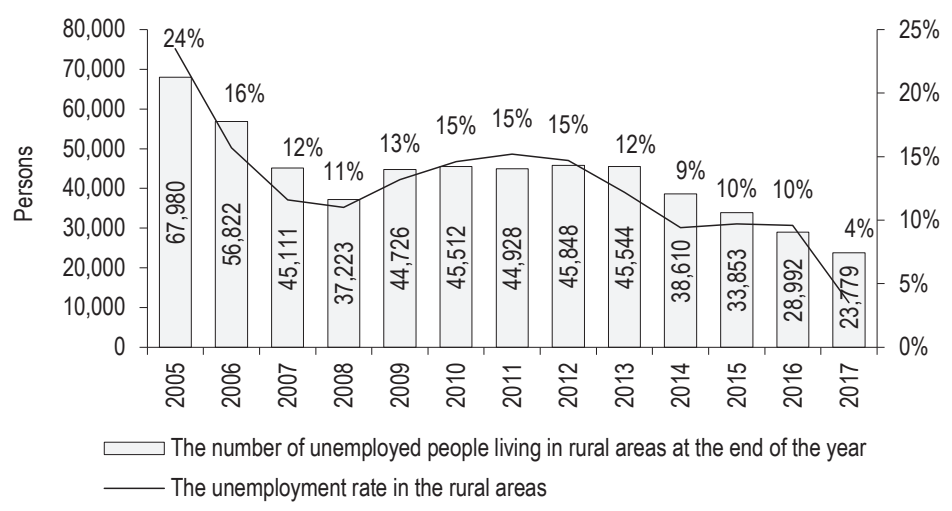

Figure 2. The number of unemployed people living in rural areas and the end of the year

Source: own study based on data from the voivodeship labour office.

During the implementation of agricultural support under the RDP for 2007-2013, unemployment in rural areas in the West Pomeranian Voivodeship remained at a similar level (about 45 thousand people). After completing this stage of funding, since 2014 unemployment has been gradually decreasing, both in absolute figures as well as in the size of the unemployment rate.

Despite the increased availability of jobs also in rural areas, there is still high international emigration (temporary and permanent). This phenomenon mainly concerns young people who may no longer return to their places of residence, which reduces the potential of the regional labour market and the possibilities of increasing the region's economic potential (com. Zieliński, 2014, pp. 63-75). For this reason, the funds received under the RDP are also to help investors who create new jobs in rural areas, inter alia, so that the villagers find employment in the region and are not forced to emigrate abroad.

\section{Implementation of the RDP in 2007-2013}

The Rural Development Program for the years 2007-2013 offered support for investments in agriculture and processing, which were to improve the competitiveness of the agri-food sector (com. Nowak, 2013). The program also included financial resources for providing assistance to investors who create new jobs in rural areas, for the development of ecological management methods and for projects that protect the natural environment and the advantages of the rural landscape. It was also possible to obtain from RDP 2007-2013 co-financing for rural renewal, actions improving the quality of life of the inhabitants and the implementation of team initiatives that stimulate the activity of local communities. The Agency for Restructuring and Modernization of Agriculture (ARiMR) was responsible for the implementation of the entire programme, under the supervision of the Ministry of Agriculture and Rural Development. 
Poland was the largest beneficiary of funds from this Program among the EU countries. There were 17.4 billion Euros available, of which approximately 13.4 billion Euros from the EU budget, the rest came from the national budget. Thanks to the funds coming from the Rural Development Program for the years 2007-2013, the largest modernization process of the Polish countryside and agri-food sector was carried out in recent years.

RDP 2007-2013 has been divided into 23 so-called measures (Podlińska, 2015, pp. 291-292). Implementation of the 15 of them was entrusted to ARiMR, and the remaining as part of delegated measures went to voivodeship self-governments, Agricultural Market Agency and Foundation of Assistance Programmes for Agriculture (FAPA). The measures listed have been included in four programme axes:

Axis 1: Improving the competitiveness of the agricultural and forestry sector.

Axis 2: Improving the condition of the natural and rural environment areas.

Axis 3: Quality of life in rural areas and diversification of the rural economy.

Axis 4: LEADER.

Measures concentrated in the first two axes served mainly to adapt the agricultural and forestry sector to the growing community-based requirements, including those related to environmental protection, and they were directed mainly to agricultural producers. Measures supported under the third axis complemented the measures defined under the first two axes and were to synergize the development of rural areas by diversifying economic activities and creating non-agricultural jobs as well as improving the quality of life in rural areas. The implementation of the measures of the fourth axis, LEADER, was based mainly on the use of knowledge and the experience of the local community for the region's development. It was important to involve the social and economic partners to plan and implement local initiatives to better define the problems of the area and find better ways to solve them.

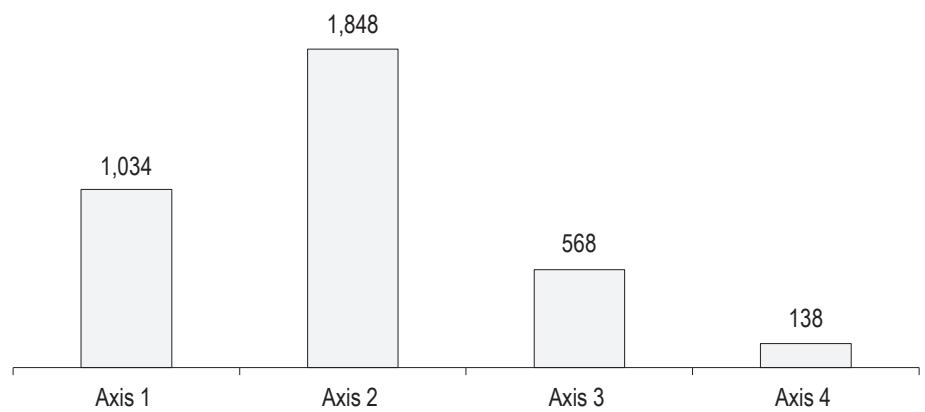

Figure 3. The amount of payments made under RDP 2007-2013 in the West Pomeranian Voivodeship (million PLN) Source: Local Data Base (2018).

The total amount of RDP funds used under 2007-2013 programmes in the West Pomeranian Voivodeship amounted to PLN 3,588 million. The largest part, PLN 1848 million, was assigned to tasks related to the improvement of the natural environment and rural areas, the smallest payments were allocated to measures from Axis 4, LEADER, which amounted to PLN 138 million. 
When assessing the use of funds under the RDP 2007-2013, it should be noted that payments made under the first axis, aimed at improving the competitiveness of the agricultural and forestry sector came in second and were lower than the funds allocated to the second axis by almost 800 thousand. PLN, which due to the nature of measures related to the first axis means that the funds from the RDP were not focused only on the development of rural areas.

A detailed breakdown of funds for individual measures has been presented in Table 1.

Table 1. Amounts of payments made under RDP 2007-2013 in the West Pomeranian Voivodeship according to individual measures (PLN)

\begin{tabular}{|c|c|c|}
\hline Axis & Measures & PROW 2007-2013 \\
\hline \multirow[t]{11}{*}{ Axis 1} & Measure 111. Professional training for people employed in agriculture and forestry & 0 \\
\hline & Measure 112. Facilitating the start of young farmers & $73,425,000$ \\
\hline & Measure 113. Structural pensions & $266,689,847$ \\
\hline & Measure 114. Use of advisory services by farmers and forest owners & 420,960 \\
\hline & Measure 121. Modernization of farms & $355,972,795$ \\
\hline & Measure 123. Increasing the added value of basic agricultural and forestry production & $142,956,521$ \\
\hline & $\begin{array}{l}\text { Measure 125. Improvement and development of infrastructure related to the development and adaptation } \\
\text { of agriculture and forestry }\end{array}$ & $120,570,047$ \\
\hline & Measure 126 . Restoring the potential of agricultural production & $4,089,988$ \\
\hline & Measure 132. Participation of farmers in food quality system & $2,896,216$ \\
\hline & Measure 141. Support for semi-subsistence farms & $23,385,495$ \\
\hline & Action 142. Groups of agricultural producers & $43,878,920$ \\
\hline \multirow[t]{4}{*}{ Axis 2} & Measure 211,212 . Supporting farming in mountainous areas and other areas with unfavourable farming conditions & $505,203,873$ \\
\hline & Measure 214. Agri-environmental programme & $1,280,449,139$ \\
\hline & Measure 221, 223. Afforestation of agricultural land and afforestation of land other than agricultural land & $45,211,079$ \\
\hline & $\begin{array}{l}\text { Measure } 226 \text {. Restoration of forest production potential damaged by disasters and the introduction of preventive } \\
\text { instruments }\end{array}$ & $17,392,827$ \\
\hline \multirow[t]{4}{*}{ Axis 3} & Measure 311. Diversification into non-agricultural activities & $38,812,173$ \\
\hline & Measure 312. Creation and development of micro-enterprises & $98,657,417$ \\
\hline & Measure 321. Basic services for the economy and rural population & $312,167,407$ \\
\hline & Measure $313,322,323$. Rural renewal and development & $118,283,427$ \\
\hline \multirow[t]{3}{*}{ Axis 4} & Measure 413. Implementation of local development strategies & $114,045,984$ \\
\hline & Measure 421. Implementation of cooperation projects & $2,409,946$ \\
\hline & Measure 431. Functioning of the local action group, acquisition of skills and activation & $21,546,341$ \\
\hline
\end{tabular}

Source: Local Data Base (2018).

The largest amount of RDP funds in 2007-2013 was used for Measure 214 under Axis 2, i.e. "Agrienvironmental program" - PLN 1280 million. This represented $35.7 \%$ of the total amount of RDP payments in this period. The second largest realized payments were also measures belonging to axis $2(211,212)$ related to "Supporting farming in mountainous areas and other areas with unfavourable farming conditions". In this area PLN 505 million was used, that is $14.1 \%$ of the total amount of RDP payments in this period. The remaining funds were heavily dispersed between the remaining measures from individual axes. 


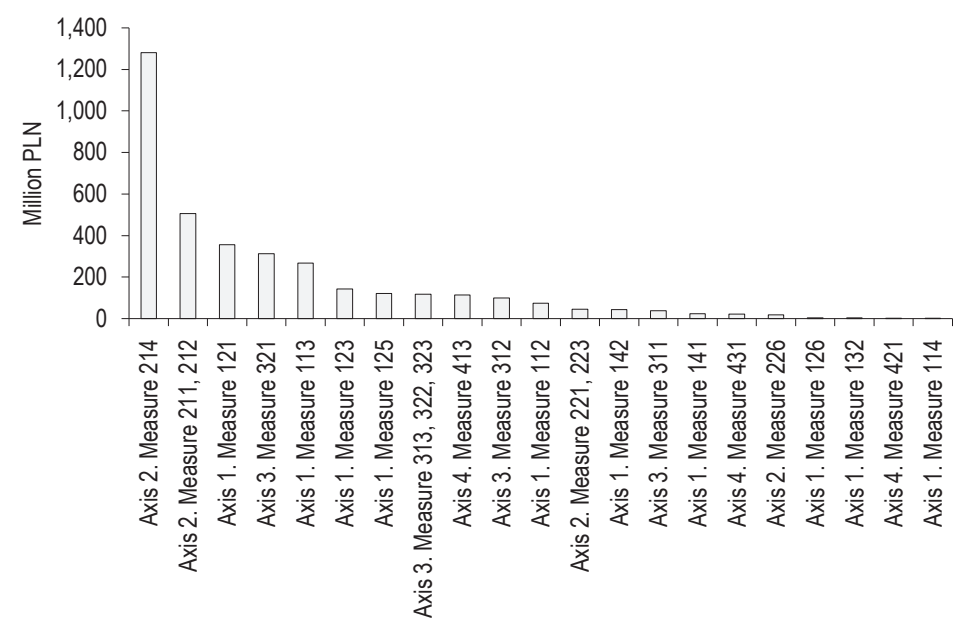

Figure 4. The amount of payments made under RDP 2007-2013 in the West Pomeranian Voivodship according to measures in individual axes

Source: Local Data Base (2018).

Although payments under Axis 1 were lower than payments made under Axis 2, it can be stated with certainty that, thanks to the RDP funds for the years 2007-2013, agricultural holdings underwent modernization, the added value of basic agricultural and forestry production was increased, many micro-enterprises were established and the existing ones could develop. Many people and farms could diversify their activities in the non-agricultural sector. These funds have also improved the quality of life in the countryside, as evidenced by modernized or equipped day-care centres, recreation and sports centres as well as the constructed water supply and sewage networks.

\section{RDP for 2014-2020}

The main objective of the Rural Development Programme for 2014-2020 is a continuation of the Programme from the years 2007-2013. It has been defined as an increase in the competitiveness of agriculture taking into account environmental objectives. The programme has been designed to implement the priorities set for the EU rural development policy, which include: ${ }^{1}$

1. Facilitating knowledge and innovation transfer in agriculture, forestry and rural areas.

2. Improving the competitiveness of all types of farming and increasing the profitability of agricultural holdings.

3. Improving the organization of the food chain and promoting risk management in agriculture.

4. Restoring, protecting and strengthening ecosystems dependent on agriculture and forestry.

5. Supporting the efficient management of resources and the transition to a low-carbon and climate resilient economy in the agricultural and food sectors and forestry.

6. Increasing social inclusion, reducing poverty and promoting economic development in rural areas.

\footnotetext{
${ }^{1}$ www.prow.info.pl.
} 
The total public funds allocated for the implementation of the Rural Development Programme for the years 2014-2020 amount to EUR 13.5 billion, of which EUR 8.6 billion will be EU funds (EAFRD) and almost EUR 5 billion will be the national contribution.

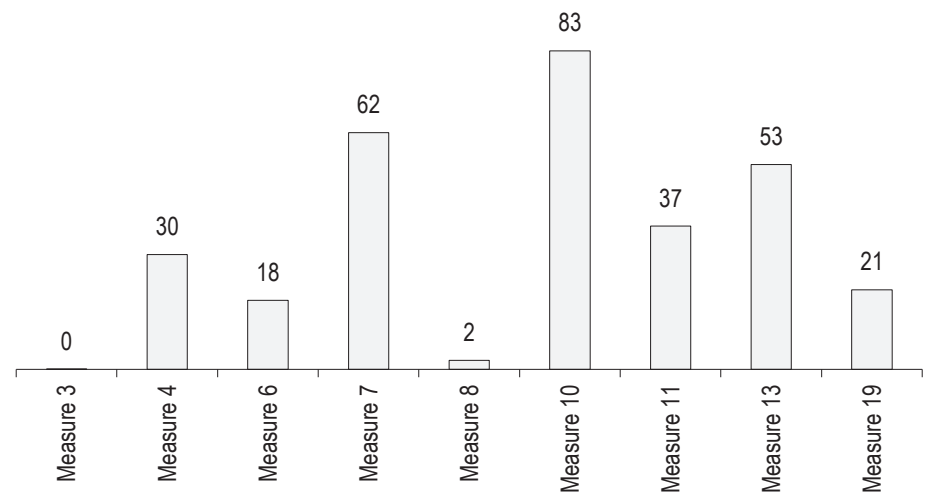

Figure 5. The amount of payments made under RDP 2014-2020 (until 30/06/2018) in the West Pomeranian Voivodeship (million PLN)

Source: Local Data Base (2018).

The total amount of RDP funds used under the 2014-2020 programs in the West Pomeranian Voivodeship until 30.06.2018 amounted to PLN 306 million. The largest part was attributable to Measure 10 "Agri environmental and climatic measure" (PLN 83 million), Measure 7 "Basic services and village renewal in rural areas" (related to the construction and modernization of local roads - PLN 62 million) and Measure 13 "Payments for areas with natural constraints or other specific restrictions" (the so-called LFA payment) (PLN 53 million).

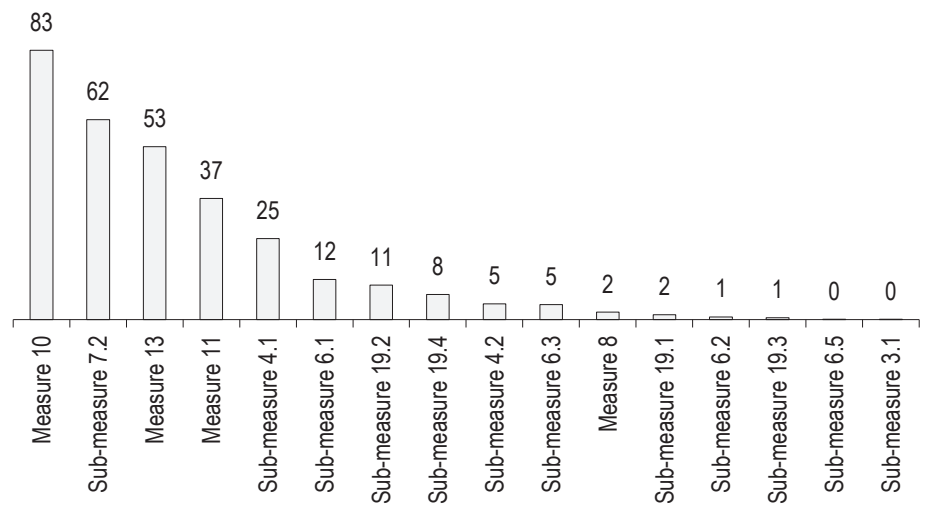

Figure b. The amount of payments made under RDP 2014-2020 to 30.06.2108 in the West Pomeranian Voivodship according to measures and sub-measures (million PLN)

Source: Local Data Base (2018). 
Most funds under the RDP for 2014-2020 in the West Pomeranian Voivodeship were used until 30.06.2018 for Measure10 Agri environmental and climatic measures - PLN 83 million. This represented $27.1 \%$ of the total amount of RDP payments in this period. The second largest realized payment was Sub-measure 7.2. Support for investments related to the creation, improvement or development of all types of small infrastructure, including investments in renewable energy and energy saving (funds were allocated for the construction or modernization of local roads) - PLN 62 million (20.1\% of the total RDP payments in this period).

\section{Conclusions}

Despite the large allocation of EU funds under the Rural Development Programme in both perspectives, the rural economy in Poland is insufficiently diversified and measures with higher added value are still needed (Smoleń, 2018, pp. 36-46). Despite a noticeable decline, ${ }^{2}$ the highest level of poverty is still in rural areas, the highest in farmers' households. Therefore, we should positively assess the fact of shifting the rural areas policy axis towards a wide range of policies relevant to life in these areas - education policy, infrastructure, entrepreneurship, environmental protection, etc., while at the same time traditional pressure is applied to the modernization of agriculture. Thanks to this, young farmers have an easier start to run their own business.

Poland has greatly benefited from joining the European Union in every respect, and in particular, in terms of the scale of funds received and used. They made it possible to pursue a policy aimed at the development of a given local government unit and in relation to RDP funds for the development of rural areas.

\section{References}

Local Data Base (2018). Retrieved from: https://bdl.stat.gov.pl/BDL/dane/podgrup/tablica.

Malkowski, A. (2017). Zachodniopomorskie rolnictwo w latach 2007-2017. Retrieved from: www.wrir.wzp.pl/sites/default/files/rolnictwo zachodniopomorskie_-_16.10.2017.pdf.

Nowak, A. (ed.) (2013). Wpływ funduszy strukturalnych na poprawę konkurencyjności polskiego rolnictwa. Warszawa: PWE.

OECD (2018). Przegląd polityki rozwoju obszarów wiejskich. Polska 2018. Wnioski i rekomendacje. Retrieved from: https://www.miir. gov.pl/media/54757/Policy_Highlights_ver_pl_ebook_21_03_2018.pdf.

Podlińska, O. (2015). Wykorzystanie środków w ramach PROW 2007-2013 w województwie mazowieckim. Studia i Prace Wydziału Nauk Ekonomicznych i Zarządzania, 37 (2), 291-292.

Smoleń, P. (ed.) (2018). Opodatkowanie rolnictwa w Polsce weryfikacja założeń perspektywa zmian. Warszawa: C.H. Beck.

Wojewódzki Urząd Pracy w Szczecinie (2018). Informacja o rynku pracy w województwie zachodniopomorskim w grudniu 2018 roku. Retrieved from: https://www.wup.pl/pl/dla-instytucji/statystyka-badania-i-analiza/dane-statystyczne.

www.prow.info.pl.

Zięba, A., Kowalski, A. (eds.) (2007). Rozwój rolnictwa gospodarki żywnościowej i obszarów wiejskich Polski w Unii Europejskiej. Warszawa: Druktur.

Zieliński, K. (2014). Procesy modernizacyjne rolnictwa. Warszawa: Difin.

Cite this article aS: Gorzałczyńska-Koczkodaj, M., Koczkodaj, R. (2018). Rural development program and its impact on rural development (on the example of the West Pomeranian Voivodeship). European Journal of Service Management, 4 (28/2), 171-178. DOI: 10.18276/ ejsm.2018.28/2-21.

$24.3 \%$ people lived in extreme poverty in 2017 against 4.9\% in 2016, and in relative poverty - slightly less than $13.4 \%$ in 2017 against $13.9 \%$ in 2016, from data of the Central Statistical Office (GUS). It means a drop in the range of extreme poverty and relative poverty. 